\title{
THE EFFECT OF SOIL CONDITIONERS ON THE QUALITY OF SELECTED FORAGE GRASSES
}

\author{
TRUBA, M. ${ }^{*}$ - JANKOWSKI, K. - WiŚNIEWSKA-KADŻAJAN, B. - SOSNOWSKI, J. - \\ MALINOWSKA, E. \\ Institute of Agriculture and Horticulture, Siedlce University of Natural Sciences and \\ Humanities, Prusa 14 Street, 08-110 Siedlce, Poland \\ (phone: +48-25-643-1318; fax: +48-25-643-1309) \\ ${ }^{*}$ Corresponding author \\ e-mail: milena.truba@uph.edu.pl \\ (Received $2^{\text {nd }}$ Dec 2019; accepted 6 ${ }^{\text {th }}$ May 2020)
}

\begin{abstract}
The aim of this paper is to determine the effect of selected soil conditioners, applied separately and with mineral fertilizers, on the intake, digestibility, and feed value of cocksfoot and perennial ryegrass. The main experimental factors were three soil conditioners with the following trade names: UGmax, Eko-Użyźniacz, and Humus Active Papka, each used on its own or together with NPK fertilizers. They were applied to the soil with two forage grasses: the Bora variety of cocksfoot and perennial ryegrass of the Info variety. In the case of cocksfoot the Humus Active Papka and UGmax soil conditioners, when both used with mineral fertilizers, had the highest impact on dry matter digestibility, but for the biomass of perennial ryegrass this parameter was the highest when Humus Active Papka was used on its own, or when UGmax was applied together with mineral fertilizers. As an average effect of fertilizer combinations, perennial ryegrass had higher digestibility, dry matter content, and relative feed value than cocksfoot. Combinations of mineral fertilizers with soil conditioners, particularly with UGmax and Humus Active Papka, resulted in the highest relative feed value of perennial ryegrass. This forage met requirements of high productive dairy cows.
\end{abstract}

Keywords: dry matter intake, dry matter digestibility, relative feed value, cocksfoot, perennial ryegrass

\section{Introduction}

According to many publications (Fernandez-Nunez et al., 2012; Gardarin et al., 2014; Barbero et al., 2020; Deroche et al., 2020) digestibility is dependent on plant species, its variety, fertilizer application, development stage at the harvest, but also on the harvest and plant preservation methods. Jankowska-Huflejt and Wróbel (2008) found that pasture grass had the highest digestibility of $66 \%$, with $64 \%$ for meadow hay, and $63 \%$ for meadow grass. In turn, Harasim (2006) reported that pasture grass digestibility was $80.9 \%$, while the figure for meadow grass was $77.6 \%$. Acid detergent fibre (ADF) and neutral detergent fibre (NDF) fractions both limit animal dry matter intake, its digestibility, and its energetic value. Additionally, many publications (Rodrigues et al., 2008; Bélanger et al., 2013; Stejskalova et al., 2013) point out that present day systems of livestock feeding for cows in particular, take into account the intake of both NDF and ADF to estimate quality of forage by working out relative feed value; thus, the NDF and ADF contents are used to determine it. Nowadays, at the time of organic farming, on the one hand, and the intensive use of mineral fertilizers and pesticides, on the other, soil conditioners are of a growing importance. They can be successfully applied to grasses, and mixtures of grasses and legumes (Sosnowski, 2012a, 2014; Sosnowski and Jankowski, 2015; Saby and Abdal-Latife, 2018; Bozhanska, 2019). Most publications on this matter deal with UGmax, and because of that, the experiment described here was set up to study the effects of other conditioners. 
The aim of this paper is to determine the effect of selected soil conditioners, applied separately and with mineral fertilizers, on the intake, digestibility, and feed value of cocksfoot and perennial ryegrass. These are good quality grass species of permanent grasslands, and, as many publications point out (Szkutnik et al., 2012; Tilvikiene et al., 2014; Georgieva et al., 2015; McDonagh et al., 2016), they are different from each other in regards the content of nutrients determining their digestibility, such as crude fibre, or NDF and ADF fractions.

\section{Materials and methods}

\section{Experiment location}

Set up in the autumn of 2011 the three-year research was conducted in the experimental field of the Institute of Agriculture and Horticulture at the University of Natural Sciences and Humanities in Siedlce $\left(52.169^{\circ} \mathrm{N}, 22.280^{\circ} \mathrm{E}\right)$, Poland. The experiment was replicated three times, with a split-plot arrangement and plots of $3 \mathrm{~m}^{2}$ as experimental units.

The experiment was conducted on the soil with the granulometric composition of light loamy sand, classified according to FAO as technosols. It was found that the soil was of neutral $\mathrm{pH}(\mathrm{pH}=6.8)$, with the concentration of carbon in organic compounds $\left(\mathrm{C}_{\mathrm{org}}\right)$ of $13.50 \mathrm{~g} \mathrm{~kg}^{-1} \mathrm{DM}$, total nitrogen concentration was $1.30 \mathrm{~g} \mathrm{~kg}^{-1} \mathrm{DM}$. Assimilable phosphorus concentration of $170 \mathrm{mg} \mathrm{kg}^{-1} \mathrm{DM}$ was high, with medium concentration of potassium (114.00 mg kg-1 DM), and high concentration of assimilable magnesium (84.00 $\left.\mathrm{mg} \mathrm{kg}^{-1} \mathrm{DM}\right)$.

\section{Experimental factors}

The main experimental factors were three soil conditioners with the trade names of Ugmax (Bogdan, Poland), Eko-Użyźniacz (Biohumuseco, Poland), and Humus Active Papka (Ekodarpol, Poland), applied separately and together with mineral fertilizers.

The UGmax soil conditioner (described as UG in the tables and figures) is an extract from compost, containing the following concentrations of macroelements $\left(\mathrm{g} \mathrm{kg}^{-1}\right)$ : nitrogen - 1.2, phosphorus - 0.2, potassium - 2.9, magnesium - 0.1 , sodium - 0.2 , and $0.3 \mathrm{mg} \mathrm{kg}^{-1}$ of manganese as a microelement. The conditioner also contains lactic acid bacteria, photosynthetic bacteria, yeast, and actionmycetes.

The main ingredients of Humus Active Papka (described as HA) are macroelements $\left(\mathrm{g} \mathrm{kg}^{-1}\right)$ : nitrogen - 0.2. phosphorus - 1.3, potassium - 4.6, calcium - 3.0, magnesium - 0.5, microelements $\left(\mathrm{mg} \mathrm{kg}^{-1}\right)$ : manganese - 15, iron - 500, zinc - 3.0, copper - 1.0, and enriched humus with beneficial microorganisms.

Eko-Użyźniacz (described as a EU) is an extract from manure vermicompost, containing mainly macroelements $\left(\mathrm{g} \mathrm{kg}^{-1}\right)$ : nitrogen - 0.6. phosphorus - 0.3. potassium 0.7 , microorganisms, and enzymes regulating metabolism of earth worms.

In the present experiment soil conditioners were used every year in spring, before the growing season, at the following doses: UGmax - $0.6 \mathrm{dm}^{3} \mathrm{ha}^{-1}$, Eko-Użyźniacz $15 \mathrm{dm}^{3} \mathrm{ha}^{-1}$, and Humus Active Papka $-50 \mathrm{dm}^{3} \mathrm{ha}^{-1}$.

Mineral fertilizers (described as NPK) were used at the following doses: $\mathrm{N}-15$, $\mathrm{P}\left(\mathrm{P}_{2} \mathrm{O}_{5}\right)-80$, and $\mathrm{K}\left(\mathrm{K}_{2} \mathrm{O}\right)-120 \mathrm{~kg} \mathrm{ha}^{-1}$. Phosphorus fertilizers were used once, in spring, while nitrogen and potassium were applied at equal doses three times a year. 
Effects of the above soil conditioners were tested on two forage grass species (second experimental factor): cocksfoot, the Bora variety, and perennial ryegrass, the Info variety, sown in the autumn of 2011 with the sowing rates of 18 and $23 \mathrm{~kg} \mathrm{ha}^{-1}$, respectively.

\section{Weather conditions}

Meteorological data for the years of research were obtained from the Hydrological and Meteorological Station in Siedlce (Fig. 1).

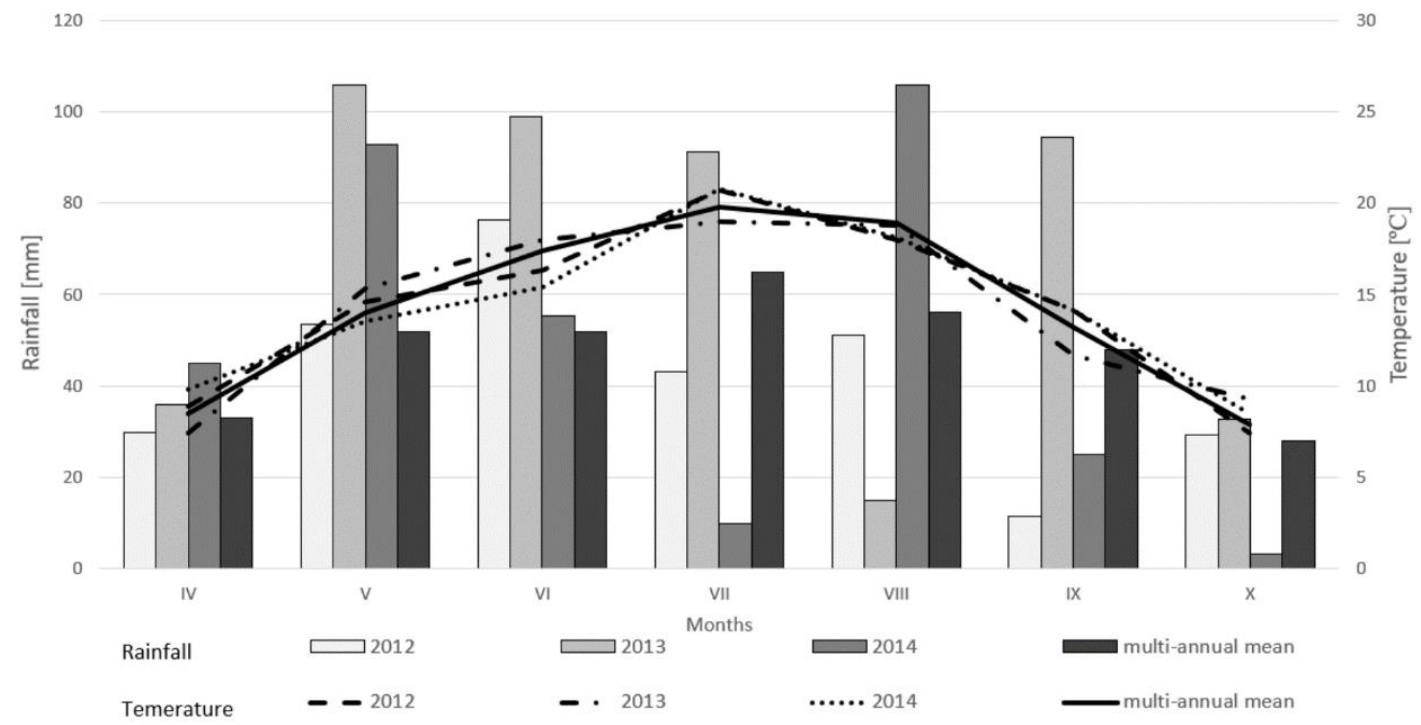

Figure 1. Average of air temperature and sum of atmospheric precipitation in the months of the growing seasons during the research

Based on the data from Figure 1, the Sielianinov's hydrothermal coefficient was calculated (Skowera and Puła, 2004) (Table 1):

$$
K=\frac{P}{0,1} \times \sum t
$$

where:

$\mathrm{K}$ - hydrothermal coefficient value (dimensionless quantity),

$\mathrm{P}$ - total monthly precipitation ( $\mathrm{mm})$,

$\mathrm{t}$ - monthly sum of air temperature $\left({ }^{\circ} \mathrm{C}\right)$.

Table 1. Sielianinov's hydrothermal coefficient values $(K)$ during the growing seasons

\begin{tabular}{c|c|c|c|c|c|c|c}
\hline \multirow{2}{*}{ Years } & \multicolumn{7}{|c}{ Months } \\
\cline { 2 - 8 } & Apr. & May & June & July & Aug. & \multicolumn{1}{c}{ Sept. } & Oct. \\
\hline 2012 & $1.12(\mathrm{md})$ & $1.22(\mathrm{md})$ & $1.56(\mathrm{o})$ & $0.69(\mathrm{sd})$ & $0.94(\mathrm{~d})$ & $0.27(\mathrm{ed})$ & $1.32(\mathrm{o})$ \\
2013 & $1.60(\mathrm{o})$ & $2.20(\mathrm{w})$ & $1.80(\mathrm{mw})$ & $1.50(\mathrm{o})$ & $0.25(\mathrm{ed})$ & $2.70(\mathrm{sw})$ & $1.22(\mathrm{md})$ \\
2014 & $1.53(\mathrm{o})$ & $2.29(\mathrm{w})$ & $1.20(\mathrm{md})$ & $0.16(\mathrm{ed})$ & $1.95(\mathrm{mw})$ & $0.59(\mathrm{sd})$ & $0.13(\mathrm{ed})$ \\
\hline
\end{tabular}

$\mathrm{K} \leq 0.4$ extreme drought (ed); $0.4<\mathrm{K} \leq 0.7$ severe drought (sd); $0.7<\mathrm{K} \leq 1.0$ drought (d); $1.0<\mathrm{K} \leq 1.3$ moderate drought (md); $1.3<\mathrm{K} \leq 1.6$ optimal (o); $1.6<\mathrm{K} \leq 2.0$ moderately wet (mw); $2.0<\mathrm{K} \leq 2.5$ wet (w); $2.5<\mathrm{K} \leq 3.0$ severely wet (sw); $\mathrm{K}>3.0$ extremely wet (ew) 


\section{Analysis}

Chemical composition of grass biomass was measured with near-infrared spectroscopy (NIRS), using the NIRFlex N-500 spectrometer (BUCHI, Poland) with the INGOT calibration package for dry feed. Acid detergent fibre (ADF) and neutral detergent fibre (NDF) concentration were used to evaluate suitability of the forage to feed livestock. It was done with Linn and Martin's test (Linn and Martin, 1989), in which a classifying parameter is relative feed value, which, in turn, was calculated using the formula:

$$
R F V=\frac{D D M \times D M I}{1.29}
$$

where:

RFV - relative feed value (dimensionless quantity),

DDM - digestible dry matter (\%).

$$
D D M=88.9-0.779 \times A D F
$$

DMI - dry matter intake (percentage of body weight).

$$
D M I=\frac{120}{N D F}
$$

Using range of values for RFV provided by Linn and Martin (1989), grass was classified to specific feed classes meeting requirements of corresponding cattle groups (Table 2).

Table 2. Cattle forage quality as relative feed value

\begin{tabular}{c|c|c}
\hline Quality class & RFV range & Animal \\
\hline I & $>151$ & Most productive dairy cows \\
II & $125-151$ & Good quality dairy cows, young heifers \\
selected for breeding
\end{tabular}

The results were statistically processed using analysis of variance for multi-factor experimental design. Tukey's test was used to determine $\mathrm{HSD}_{0.05}$, and Statistica 12 software was applied for calculations.

\section{Results and discussion}

\section{Evaluation of cocksfoot and perennial ryegrass digestible dry matter}

According to Stachowicz (2010) the digestibility of grass forage, as feed for ruminants, should be at least $65 \%$. As regards dry matter digestibility, average of experimental years and treatments, it was found that mean values of this parameter for cocksfoot and perennial ryegrass were significantly different, with $65.9 \%$ and $66.9 \%$, respectively 
(Table 3). Other publications provide similar results (Downing and Gamroth, 2007; McDonagh et al., 2016; Cupic et al., 2019), stressing the fact that perennial ryegrass is easily digestible because it contains low amounts of such compounds as crude fibre, neutral detergent fibre, and acid detergent fibre. According to many authors (Szkutnik et al., 2012; Tilvikiene et al., 2014; Georgieva et al., 2015) cocksfoot contains too much of the above compounds, which lowers its digestibility.

Table 3. The effects of year and fertilizer on digestible dry matter (\%)

\begin{tabular}{|c|c|c|c|c|c|c|c|c|c|}
\hline \multirow{2}{*}{$\begin{array}{c}\text { Species / } \\
\text { Year / } \\
\text { Cutting }\end{array}$} & \multicolumn{8}{|c|}{ Fertilizer } & \multirow{2}{*}{ Mean } \\
\hline & 0 & NPK & $\mathbf{U G}$ & $\mathbf{E U}$ & HA & UG+NPK & EU+NPK & HA+NPK & \\
\hline \multicolumn{10}{|c|}{ Mean for species } \\
\hline Cocksfoot & $65.5^{\mathrm{Ba}}$ & $65.4^{\mathrm{Aa}}$ & $65.3^{\mathrm{Aa}}$ & $66.0^{\mathrm{Aa}}$ & $66.1^{\mathrm{Aa}}$ & $66.4^{\mathrm{Aa}}$ & $65.8^{\mathrm{Aa}}$ & $66.4^{\mathrm{Aa}}$ & $65.9^{\mathrm{B}}$ \\
\hline $\begin{array}{c}\text { Perennial } \\
\text { ryegrass }\end{array}$ & $67.5^{\mathrm{Aa}}$ & $66.1^{\mathrm{Aa}}$ & $65.9^{\mathrm{Aa}}$ & $67.4^{\mathrm{Aa}}$ & $67.5^{\mathrm{Aa}}$ & $67.5^{\mathrm{Aa}}$ & $66.4^{\mathrm{Aa}}$ & $67.1^{\mathrm{Aa}}$ & $66.9^{\mathrm{A}}$ \\
\hline \multicolumn{10}{|c|}{ Mean for cuttings } \\
\hline I & $66.2^{\mathrm{Aa}}$ & $64.8^{\mathrm{Aa}}$ & $65.0^{\mathrm{Aa}}$ & $65.3^{\mathrm{Ba}}$ & $66.2^{\mathrm{Aa}}$ & $66.5^{\mathrm{Aa}}$ & $64.8^{\mathrm{Aa}}$ & $65.9^{\mathrm{Aa}}$ & $65.6^{\mathrm{B}}$ \\
\hline II & $66.0^{\mathrm{Aab}}$ & $65.3^{\mathrm{Ab}}$ & $65.8^{\mathrm{Aab}}$ & $67.9^{\mathrm{Aa}}$ & $66.8^{\text {Aab }}$ & $66.9^{\mathrm{Aab}}$ & $66.6^{\mathrm{Aab}}$ & $66.9^{\mathrm{Aab}}$ & $66.5^{\mathrm{A}}$ \\
\hline III & $67.3^{\mathrm{Aa}}$ & $67.3^{\mathrm{Aa}}$ & $66.1^{\mathrm{Aa}}$ & $67.0^{\mathrm{Aa}}$ & $67.3^{\mathrm{Aa}}$ & $67.5^{\mathrm{Aa}}$ & $66.9^{\text {Аa }}$ & $67.4^{\mathrm{Aa}}$ & $67.1^{\mathrm{A}}$ \\
\hline \multicolumn{10}{|c|}{ Mean for years } \\
\hline 2012 & $65.9^{\mathrm{Ab}}$ & $65.5^{\mathrm{Ab}}$ & $65.7^{\mathrm{Ab}}$ & $66.3^{\mathrm{ABab}}$ & $67.2^{\text {Aab }}$ & $68.2^{\mathrm{Aa}}$ & $66.2^{\mathrm{Ab}}$ & $67.2^{\mathrm{Aab}}$ & $66.5^{\mathrm{AB}}$ \\
\hline 2013 & $67.1^{\mathrm{Aab}}$ & $66.6^{\mathrm{Aab}}$ & $65.9^{\mathrm{Ab}}$ & $68.0^{\mathrm{Aa}}$ & $67.0^{\mathrm{Aab}}$ & $66.6^{\mathrm{ABab}}$ & $66.3^{\text {Aab }}$ & $67.4^{\mathrm{Aab}}$ & $66.9^{\mathrm{A}}$ \\
\hline 2014 & $66.5^{\mathrm{Aa}}$ & $65.3^{\mathrm{Aa}}$ & $65.3^{\mathrm{Aa}}$ & $65.9^{\mathrm{Ab}}$ & $66.2^{\mathrm{Aa}}$ & $66.1^{\mathrm{Ba}}$ & $65.8^{\mathrm{Aa}}$ & $65.7^{\mathrm{Aa}}$ & $65.9^{\mathrm{B}}$ \\
\hline
\end{tabular}

Means in lines marked with the same small letters do not differ significantly. Means in columns marked with the same capital letters do not differ significantly

When both UGmax and mineral fertilizers were used not together but separately, the digestibility of forage from both plots was lower, with $65.6 \%$ and $65.8 \%$, respectively. In the forage form those plots, with UGmax or mineral fertilizers applied, it was $1.4 \%$ lower than in the control (Table 3). Jankowska-Huflejt and Wróbel (2008) found similar results studying digestibility of forage from permanent grassland. They found that it ranged from 63 to $66 \%$ for green grass, while for hay it was 64\%. Harasim (2006), however, presents much higher values found in research on grass from permanent grassland, with its digestibility ranging from 77.6 to $80.9 \%$. In the experiment presented here, for both grass species and all combinations of fertilizers the digestibility of the second year forage (2013) was the highest (66.9\%) and significantly different form the value of the same parameter in the third year (2014), which was $65.9 \%$. There is a relationship between the value of hydrothermal coefficient and the above values. In the second year weather conditions were rather optimal and forage digestibility was the highest, while in the third year most of the growing season was dry to extremely dry, which resulted in lower digestibility.

Comparing forage from the two grass species from all experimental units it was found that the application of soil conditioners and mineral fertilizers did not significantly affect digestibility of cocksfoot (Table 3). But mineral fertilisers and UGmax, when both applied on their own, slightly lowered digestibility of perennial ryegrass, by $2.4 \%$, compared to the control. Sosnowski (2012a) noticed a similar reaction of plants to fertilizers in an experiment with Festulolium brauni, where its digestibility was $60 \%$, not 
being affected by a soil conditioner, while mineral fertilizers significantly lowered it to $48.5 \%$.

Analysing dry matter digestibility in consecutive harvests in the same growing seasons it was found that it significantly increased, from $65.6 \%$ in the first one, to $67.1 \%$ in the third one.

It was found that the treatment effect on digestibility was the highest on plots where mineral fertilizers and UGmax were applied together. However, this value did not differ significantly from that in the control (Fig. 2), but the increase caused by this combined application (about 1.8\%) was statistically significant when compared to the effect of the soil conditioner used on its own. In the case of other soil conditioners their use together with mineral fertilization or separately, did not cause significant differences.

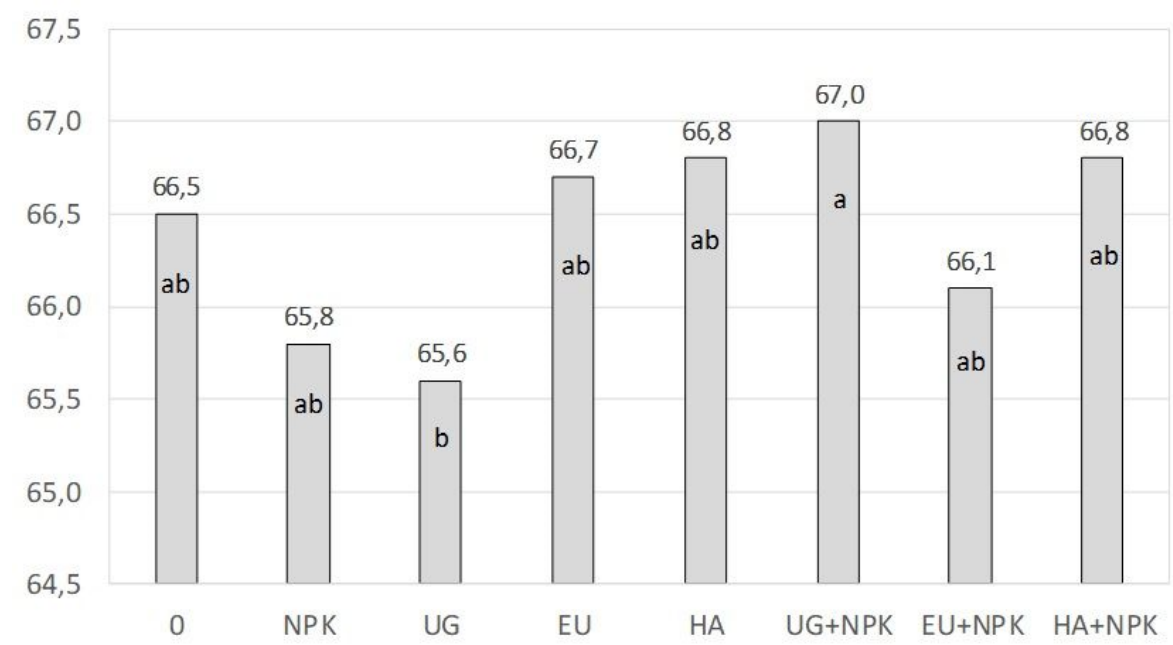

Figure 2. The effects of fertilizer on digestible dry matter (\%). Means in columns marked with the same lower case letters do not differ significantly

\section{Dry matter intake for cocksfoot and perennial ryegrass}

According to Deroche et al. (2020) forage quality depends on the development stage at which plants are harvested. Together with plant aging its nutritional value is declining because the amount of crude fibre is going up, which in turn affects dry matter intake and dry matter digestibility.

By comparing both grass species (Table 4) it was found that perennial ryegrass had significantly higher dry matter intake $(2.83 \%)$ than cocksfoot $(2.60 \%)$. Cocksfoot from the plot where Eko-Użyźniacz was applied had a significantly higher dry matter intake $(2.77 \%)$ than the same grass species from the control plot. There were no significant differences between the forage coming from other plots.

The highest dry matter intake $(2.98 \%)$ was for perennial ryegrass coming from the plots where UGmax and mineral fertilizers were used together $(2.98 \%)$, and from the ones where Humus Active Papka with mineral fertilizers was used (3.0\%). However, the parameters did not differ significantly from the results on the control plot. Dry matter intake was significantly lower, by $9.4 \%$, for perennial ryegrass from the plot with UGmax (2.63\%). Sosnowski (2012b) proved that the UGmax soil conditioner slightly raised perennial ryegrass dry matter intake, from 2.44 to $2.52 \%$, whereas the same conditioner slightly decreased it in cocksfoot, from 2.20 to $2.11 \%$. The results of dry matter intake in 
the present experiment are higher than those provided by Jankowska-Huflejt and Wróbel (2008), who found that it ranged from $1.96 \%$ for hay, to $2.42 \%$ for pasture grass, while Moore and Undersander (2002) found that dry matter intake for forage ranged from 1.93 to $2.17 \%$. The analysis of this parameter in different cuttings of grass for both species and all fertilizer combinations proved that it steadily increased in consecutive cuttings.

Table 4. The effects of fertilizer and year of the experiment on dry matter intake (percentage of body weight)

\begin{tabular}{|c|c|c|c|c|c|c|c|c|c|}
\hline \multirow{2}{*}{$\begin{array}{c}\text { Species / } \\
\text { Year / } \\
\text { Cutting } \\
\end{array}$} & \multicolumn{8}{|c|}{ Fertilizer } & \multirow{2}{*}{ Mean } \\
\hline & $\mathbf{0}$ & NPK & $\mathbf{U G}$ & $\mathbf{E U}$ & HA & UG+NPK & EU+NPK & HA+NPK & \\
\hline \multicolumn{10}{|c|}{ Mean for species } \\
\hline Cocksfoot & $2.54^{\mathrm{Bab}}$ & $2.45^{\mathrm{Ab}}$ & $2.51^{\mathrm{Aab}}$ & $2.77^{\mathrm{Aa}}$ & $2.68^{\mathrm{Aab}}$ & $2.61^{\mathrm{Bab}}$ & $2.51^{\mathrm{Bab}}$ & $2.69^{\mathrm{Bab}}$ & $2.60^{\mathrm{A}}$ \\
\hline $\begin{array}{c}\text { Perennial } \\
\text { ryegrass }\end{array}$ & $2.91^{\mathrm{Aab}}$ & $2.74^{\mathrm{Aab}}$ & $2.63^{\mathrm{Ab}}$ & $2.76^{\mathrm{Aab}}$ & $2.75^{\mathrm{Aab}}$ & $2.98^{\mathrm{Aa}}$ & $2.87^{\mathrm{Aab}}$ & $3.00^{\mathrm{Aa}}$ & $2.83^{\mathrm{A}}$ \\
\hline \multicolumn{10}{|c|}{ Mean for cuttings } \\
\hline I & $2.72^{\mathrm{Aa}}$ & $2.43^{\mathrm{Aa}}$ & $2.41^{\mathrm{Aa}}$ & $2.67^{\mathrm{Aa}}$ & $2.59^{\mathrm{Aa}}$ & $2.70^{\mathrm{Aa}}$ & $2.56^{\mathrm{Aa}}$ & $2.78^{\mathrm{Aa}}$ & $2.61^{\mathrm{B}}$ \\
\hline II & $2.59^{\mathrm{Aa}}$ & $2.56^{\mathrm{Aa}}$ & $2.60^{\mathrm{Aa}}$ & $2.84^{\mathrm{Aa}}$ & $2.71^{\mathrm{Aa}}$ & $2.80^{\mathrm{Aa}}$ & $2.78^{\mathrm{Aa}}$ & $2.83^{\mathrm{Aa}}$ & $2.71^{\mathrm{AB}}$ \\
\hline III & $2.86^{\mathrm{Aa}}$ & $2.80^{\mathrm{Aa}}$ & $2.70^{\mathrm{Aa}}$ & $2.80^{\mathrm{Aa}}$ & $2.84^{\mathrm{Aa}}$ & $2.87^{\mathrm{Aa}}$ & $2.71^{\mathrm{Aa}}$ & $2.93^{\mathrm{Aa}}$ & $2.81^{\mathrm{A}}$ \\
\hline \multicolumn{10}{|c|}{ Mean for years } \\
\hline 2012 & $2.65^{\mathrm{Aab}}$ & $2.62^{\text {Aab }}$ & $2.58^{\mathrm{Ab}}$ & $2.79^{\mathrm{Aab}}$ & $2.93^{\mathrm{Aab}}$ & $2.93^{\mathrm{Aab}}$ & $2.76^{\mathrm{Aab}}$ & $3.02^{\mathrm{Aa}}$ & $2.79^{\mathrm{A}}$ \\
\hline 2013 & $2.85^{\mathrm{Aa}}$ & $2.66^{\mathrm{Aa}}$ & $2.62^{\mathrm{Aa}}$ & $2.93^{\mathrm{Aa}}$ & $2.63^{\mathrm{Aa}}$ & $2.69^{\mathrm{Aa}}$ & $2.71^{\mathrm{Aa}}$ & $2.84^{\mathrm{Aa}}$ & $2.74^{\mathrm{AB}}$ \\
\hline 2014 & $2.67^{\mathrm{Aa}}$ & $2.50^{\mathrm{Aa}}$ & $2.51^{\mathrm{Aa}}$ & $2.58^{\mathrm{Aa}}$ & $2.58^{\mathrm{Aa}}$ & $2.75^{\mathrm{Aa}}$ & $2.59^{\mathrm{Aa}}$ & $2.68^{\mathrm{Aa}}$ & $2.61^{\mathrm{B}}$ \\
\hline
\end{tabular}

Means in lines marked with the same small letters do not differ significantly. Means in columns marked with the same capital letters do not differ significantly

Analysing the effect of fertilizers on dry matter intake (Fig. 3), calculated by using the content of neutral detergent fibre, it was found that the lowest value of this parameter was for the forage from the plots where UGmax (2.57\%) and NPK fertilizers $(2.59 \%)$ where applied separately.

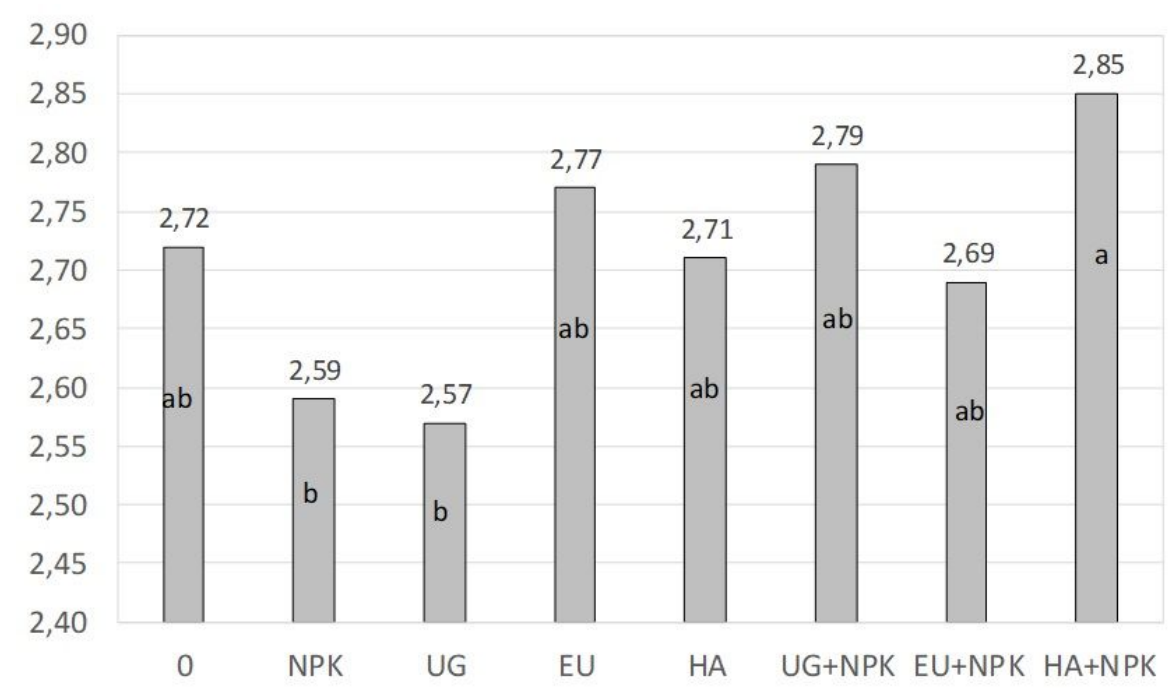

Figure 3. The effects of fertilizer on dry matter intake (percentage of body weight). Means in columns marked with the same lower case letters do not differ significantly 
However, when UGmax and NPK fertilizers were applied together, the amount of dry matter significantly increased (to $2.79 \%$ ), compared to the plots where they were used separately. The highest increase of this parameter was in the grass from the plot where Humus Active Papka together with mineral fertilizers was applied (2.85\%); it was about $5 \%$ higher than in the forage from the control. Comparing this parameter in each experimental year it was found that the highest dry matter intake $(2.79 \%)$ was in the first year (2012), and it decreased in consecutive years. Analysing dry matter intake for all three harvests it was observed that it significantly decreased, from $2.79 \%$ in the first one, to $2.61 \%$ in the third one.

\section{Relative feed value}

Linn and Martin's test (1989) applied in the present experiment showed that, as an average for both grass species, the forage from all plots is of second quality class. Comparing experimental years only, it was discovered that the grass had the highest value in the first year (144), and it was gradually lower in the consecutive years (Table 5).

Table 5. The effects of experimental year and fertilizer on dry matter relative feed value

\begin{tabular}{|c|c|c|c|c|c|c|c|c|c|}
\hline \multirow{2}{*}{$\begin{array}{c}\text { Species / } \\
\text { Year / } \\
\text { Cutting } \\
\end{array}$} & \multicolumn{8}{|c|}{ Fertilizer } & \multirow{2}{*}{ Mean } \\
\hline & $\mathbf{0}$ & NPK & UG & $\mathbf{E U}$ & HA & UG+NPK & EU+NPK & HA+NPK & \\
\hline \multicolumn{10}{|c|}{ Mean for species } \\
\hline Cocksfoot & $129^{\mathrm{Ba}}$ & $125^{\mathrm{Aa}}$ & $127^{\mathrm{Aa}}$ & $142^{\mathrm{Aa}}$ & $138^{\mathrm{Aa}}$ & $134^{\mathrm{Ba}}$ & $128^{\mathrm{Ba}}$ & $139^{\mathrm{Aa}}$ & $133^{\mathrm{B}}$ \\
\hline $\begin{array}{c}\text { Perennial } \\
\text { ryegrass }\end{array}$ & $152^{\mathrm{Aab}}$ & $141^{\text {Aab }}$ & $135^{\mathrm{Ab}}$ & $145^{\mathrm{Aab}}$ & $144^{\mathrm{Aab}}$ & $156^{\mathrm{Aa}}$ & $148^{\mathrm{Aab}}$ & $156^{\mathrm{Aa}}$ & $147^{\mathrm{A}}$ \\
\hline \multicolumn{10}{|c|}{ Mean for cuttings } \\
\hline I & $140^{\mathrm{Aa}}$ & $122^{\mathrm{Aa}}$ & $122^{\mathrm{Aa}}$ & $135^{\mathrm{Aa}}$ & $134^{\mathrm{Aa}}$ & $140^{\mathrm{Aa}}$ & $129^{\text {Aa }}$ & $143^{\mathrm{Aa}}$ & $133^{\mathrm{C}}$ \\
\hline II & $132^{\mathrm{Aa}}$ & $130^{\mathrm{Aa}}$ & $133^{\mathrm{Aa}}$ & $150^{\mathrm{Aa}}$ & $141^{\mathrm{Aa}}$ & $146^{\mathrm{Aa}}$ & $144^{\mathrm{Aa}}$ & $147^{\mathrm{Aa}}$ & $140^{\mathrm{B}}$ \\
\hline III & $150^{\mathrm{Aa}}$ & $146^{\mathrm{Aa}}$ & $139^{\mathrm{Aa}}$ & $146^{\mathrm{Aa}}$ & $148^{\mathrm{Aa}}$ & $150^{\mathrm{Aa}}$ & $141^{\mathrm{Aa}}$ & $153^{\mathrm{Aa}}$ & $147^{\mathrm{A}}$ \\
\hline \multicolumn{10}{|c|}{ Mean for years } \\
\hline 2012 & $136^{\text {Aab }}$ & $133^{\text {Aab }}$ & $132^{\mathrm{Ab}}$ & $144^{\mathrm{Aab}}$ & $152^{\text {Aab }}$ & $155^{\mathrm{Aab}}$ & $142^{\text {Aab }}$ & $158^{\mathrm{Aa}}$ & $144^{\mathrm{A}}$ \\
\hline 2013 & $149^{\mathrm{Aa}}$ & $138^{\mathrm{Aa}}$ & $134^{\mathrm{Aa}}$ & $155^{\mathrm{Aa}}$ & $137^{\mathrm{Aa}}$ & $139^{\mathrm{Aa}}$ & $140^{\mathrm{Aa}}$ & $149^{\mathrm{Aa}}$ & $143^{\mathrm{AB}}$ \\
\hline 2014 & $138^{\mathrm{Aa}}$ & $127^{\mathrm{Aa}}$ & $127^{\mathrm{Aa}}$ & $132^{\mathrm{Aa}}$ & $133^{\mathrm{Aa}}$ & $141^{\mathrm{Aa}}$ & $132^{\mathrm{Aa}}$ & $137^{\mathrm{Aa}}$ & $133^{\mathrm{B}}$ \\
\hline
\end{tabular}

Means in lines marked with the same small letters do not differ significantly. Means in columns marked with the same capital letters do not differ significantly

Comparing both grass species (Table 5) it was found that perennial ryegrass had a significantly higher RFV (147) than cocksfoot (133). The results indicate that only perennial ryegrass from the plot with UGmax and mineral fertilizers applied together (156) and form the plot with Humus Active Papka and mineral fertilizers applied together (156) was of the first quality class.

The above results indicate that that forage met requirements of high productivity dairy cows. Perennial ryegrass from the control plot also had a high RVF value (152). Forage from other plots was classified to the second class, to be used to feed good dairy cows and young heifers selected for breeding. According to Sosnowski (2012b) perennial ryegrass had a lower RFV (119), but UGmax application slightly raised it (124). The same author (2012d) found that for cocksfoot relative feed value was 104 and after UGmax application this parameter decreased to 100 . Comparing relative feed value of forage from 
different grass cuttings it was found that it increased significantly, rising from133 in the first cutting to 147 in the third.

Grass from plots where UGmax with mineral fertilizers and form plots where Humus Active Papka with mineral fertilizers were applied had the highest feed value, 145 and 148, respectively (Fig. 4). Compared to the plot where both of them were applied together, separate application of UGmax and mineral fertilizers lowered relative feed value by $9 \%$.

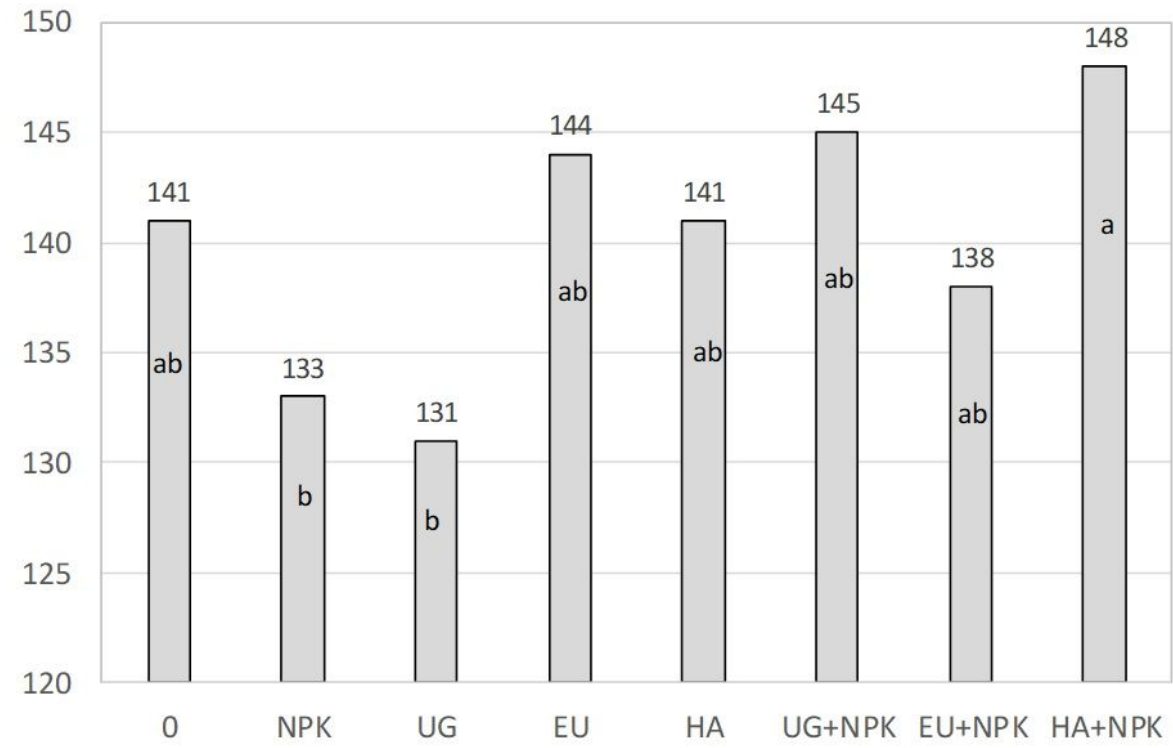

Figure 4. The effects of fertilizer on relative feed value in dry matter (-). Means in columns marked with the same lower case letters do not differ significantly

\section{Conclusions}

1. In the case of cocksfoot the Humus Active Papka and UGmax soil conditioners, when both used with mineral fertilizers, had the highest impact on dry matter digestibility, but in the biomass of perennial ryegrass this parameter was the highest when Humus Active Papka was used on its own, or when UGmax was applied together with mineral fertilizers.

2. As an average affect of fertilizer combinations, perennial ryegrass had higher digestibility, dry matter content, and relative feed value than cocksfoot.

3. Combinations of mineral fertilizers with soil conditioners, in particular with UGmax and Humus Active Papka, resulted in the highest relative feed value of perennial ryegrass. This forage met requirements of high productive dairy cows.

4. The diverse and inconclusive results of the experiment with the nutritional value of perennial ryegrass and cocksfoot indicate that there should be further research conducted to select the most suitable soil conditioner to be used for growing forage grass.

Acknowledgements. The research carried out under the theme No. 171/16/MN was financed from the science grant of the Ministry of Science and Higher Education - Poland. 


\section{REFERENCES}

[1] Barbero, R. P., Malheiros, E. B., Aguilar, N. M., Romanzini, E. P., Ferrari, A. C., Nave, R. L., Mullinks, J. T., Reis, R. A. (2020): Supplementation level increasing dry matte intake of beef cattle grazing low herbage height. - Journal of Applied Animal Research 48(1): 2833. doi:10.1080/09712119.2020.1715985.

[2] Bélanger, G., Virkajarvi, P., Duru, M., Tremblay, G. F., Saarijarvi, K. (2013): Herbage nutritive in less - favoured areas of cool regions. - The Role of Grasslands in a Green Future, EGF, Grassland Science in Europe 18: 57-70.

[3] Bozhanska, T. (2019): Study on the influence of Lumbricl and Lumbrex bio-fertilizers over an artificial grassland of red fescue (Festuca rubra L.). - Bulgarian Journal of Agricultural Science 25(2): 278-282.

[4] Cupic, T., Varnica, I., Jukic, G., Krizmanic, G., Tucak, M., Popovic, S., Babic, I., Simic, A. (2019): Forage grass productivity and quality in south-western part of Pannonian basin. - Journal of Central European Agriculture 20(1): 341-352. doi:10.5513/JCEA01/20.1.2215.

[5] Deroche, B., Pradel, P., Baumont, R. (2020): Long-term evolution and prediction of feed value for permanent mountain grassland hay: Analysis of a 32-year data set in relation to climate change. - Grassland and Forage Science 75(1): 18-27. doi:10.1111/gfs.12465.

[6] Downing, T., Gamroth, M. (2007): Nonstructural Carbohydrates in Cool - season Grasses. - Oregon State University Extension Service. Special Report 1079-E.

[7] Fernandez-Nunez, E., Pires, J. M., Fernandes, A., Pires, J., Aguiar, C., Galvao, L., Moreira, N. (2012): Grazing regimes and fertilization rates: effect on dry matter yield, crude protein content and digestibility of meadows in the Northeast of Portugal. Grassland - a European Resource? - EGF. Grassland Science in Europe 17: 311-313.

[8] Gardarin, A., Garnier, E., Carrère, P., Cruz, P., Andueza, D., Bonis, A., Colace, M. P., Dumont, B., Duru, M., Farruggia, A., Gaucherand, S., Grigulis, K., Kernéïs, E., Lavorel, S., Louault, F., Loucougaray, G., Mesléard, F., Yavercovski, N., Kazakou, E. (2014): Plant trait-digestibility relationship across management and climate gradients in permanent grasslands. - Journal of Applied Ecology 51(5): 1207-1217. doi:10.1111/13652664.12293.

[9] Georgieva, N., Pachev, I., Katova, A., Naydenova, Y. (2015): Study of introduced varieties of Perennial grass species grown in the conditions of central northern Bulgaria. - Banat's Journal of Biotechnology 6(12). doi:10.7904/2068-4738-VI(12)-20.

[10] Harasim, J. (2006): Productivity of grassland communities used for hay and grazing as permanent grass or leys changes. - Annales UMCS sectio E Agricultura LXI: 165-173. (in Polish).

[11] Jankowska-Huflejt, H., Wróbel, B. (2008): Evaluation of usefulness of forages from grasslands in livestock production in examined organic farms. - Journal of Research and Application in Agricultural Engineering 53(3): 103-108. (in Polish).

[12] Linn, J. G., Martin, N. P. (1989): Forage quality test and interpretation. - Minnesota Extension Service, University of Minnesota, 1-5.

[13] McDonagh, J., O’Donovan, M., McEvo, M., Gilliland, T. J. (2016): Genetic gain in perennial ryegrass (Lolium perenne) varieties 1973 to 2013. - Euphytica 212(2): 187-199. doi:10.1007/s10681-016-1754-7.

[14] Moore, J. E., Undersander, D. J. (2002): Relative Forage Quality: An Alternative to Relative Feed Value and Quality Index. - Proceedings $13^{\text {th }}$ Annual Florida Ruminant Nutrition Symposium: 16-32.

[15] Rodrigues, A. M., Andueza, D., Picard, F., Cecato, U., Farruggia, A., Baumont, R. (2008): Classification of mountain permanent grasslands based on their feed value. - Biodiversity and animal feed, EGF. Grassland Science in Europe 13: 501-503.

[16] Sabry, R. E., Abdal-Latife, S. A. (2018): Effect of bio fertilizers on growth of some turfgrass pants. - Iraqi Journal of Agricultural Sciences 48(6B): 1624-1633. 
[17] Skowera, B., Puła, J. (2004): Pluviometric extreme conditions in sping season in Poland in the years 1971 - 2000. - Acta Agrophysica 3(1): 171-177. (in Polish).

[18] Sosnowski, J. (2012a): Reaction of Dactylis glomerata L. Festuca pratensis Huds. and Lolium perenne L. to microbiological fertilizer and mineral fertilization. - Acta Scientiarum Polonorum, Agricultura 11(1): 91-98.

[19] Sosnowski, J. (2012b): Effect of soil's fertilizer used in cultivation Lolium perenne L., Dactylis glomerata L. and Festuca pratensis Huds. On relative value (RFV) of food. Fragmenta Agronomica 29(3): 136-143. (in Polish).

[20] Sosnowski, J., Jankowski, K., Wiśniewska-Kadżajan, B. (2014): Evaluation of the impact of selected microbiological preparations on the development of the aboveground biomass of Trifolium pretense L. - Environmental Protection and Natural Resources 25(3): 1-4. doi:10.2478/oszn-2014-0010.

[21] Sosnowski, J., Jankowski, K. (2015): The Applicability of Soil's Fertilizers in Increasing of Production Effects in Lolium Perenne and Lolium Multiflorum Cultivation. - Journal of Life Science 9: 91-94. doi:10.17265/1934-7391/2015.03.001.

[22] Stachowicz, T. (2010): The rational use of grassland in ecological farm. - The Agricultural Advisory Centre in Brwinow, Radom. (in Polish).

[23] Stejskalova, M., Hejcmanova, P., Hejcman, M. (2013): Forage value of leaf fodder main European broad - leaved woody species. - The Role of Grassland in a Green Future, EGF. Grassland Science in Europe 18: 85-87.

[24] Szkutnik, J., Kacorzyk, P., Szewczyk, W. (2012): The content change of total protein and crude fibre depending on the dose of fertilization and phenological phase of grasses. Grassland Science in Poland 15: 185-191. (in Polish).

[25] Tilvikiene, V., Kadziuliene, Z., Dabkevicius, Z., Sarunaite, L., Slepetys, J., Pociene, L., Slepetiene, A., Ceceviciene, J. (2014): The yield and variation of chemical composition of cocksfoot biomass after five years of digestate application. - The Future of European Grasslands, EGF. Grassland Science in Europe 19: 468-470. 